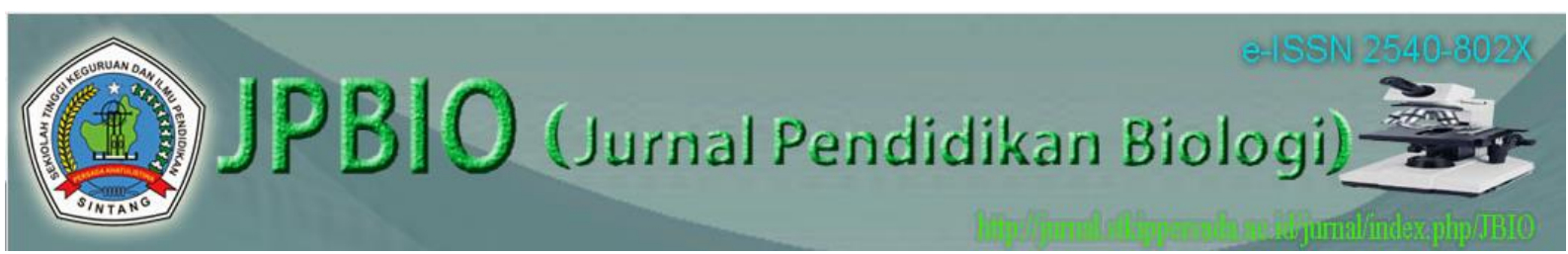

JPBIO (Jurnal Pendidikan Biologi)

Vol. 1 No. 1 November 2016 | 1 - 10

ISSN 2540-802x (Online)

DOI: http://dx.doi.org/10.31932/ JPBIO (Jurnal Pendidikan Biologi)

http://jurnal.stkippersada.ac.id/jurnal/index.php/JBIO

\title{
PENERAPAN MODEL PEMBELAJARAN CONTEXTUAL TEACHING AND LEARNING (CTL) TERHADAP MOTIVASI DAN HASIL BELAJAR KOGNITIF PADA MATERI MENGIDENTIFIKASI CARA MAKHLUK HIDUP MENYESUAIKAN DIRI DENGAN LINGKUNGANNYA
}

\author{
Jimi $^{1}$, F.R. Esti Wahyuni, S,Si., M.Pd ${ }^{2 *}$, Yasinta Lisa, S.Si., M.Cs ${ }^{3}$
}

1Mahasiswa Program Studi Pendidikan Biologi, STKIP Persada Khatulistiwa Sintang 2,3Dosen Program Studi Pendidikan Biologi, STKIP Persada Khatulistiwa Sintang

E-mail: jimistail1994@gmail.com, esti_pandi@ymail.com, yasintalisa@gmail.com

Diterima: 02 April 2016 Direvisi: 10 Mei $2016 \quad$ Disetujui: 03 Oktober 2016

\begin{abstract}
ABSTRAK
Penelitian ini bertujuan untuk mendeskripsikan penerapan model pembelajaran Contextual Teaching And Learning (CTL) terhadap motivasi dan hasil belajar kognitif pada materi mengidentifikasi cara makhluk hidup menyesuaikan diri dengan lingkungannya siswa kelas VB SD Negeri 03 Ranyai Hilir. Bentuk penelitian dalam penelitian ini adalah Quasi Eksperimental Design dengan desain Nonequivalent Control Group Design. Hasil uji hipotesis post-angket pada kelas eksperimen dan kelas kontrol diperoleh nilai $t_{\text {hitung }}(8,75)>$ $\mathrm{t}_{\text {tabel }}(2,032)$, artinya terdapat perbedaan yang signifikan motivasi belajar siswa antara kelas eksperimen dan kelas kontrol pada post-angket. Hasil uji hipotesis post-test pada kelas eksperimen dan kelas kontrol diperoleh nilai thitung $(6,219)>t_{\text {tabel }}(2,032)$, artinya terdapat perbedaan yang signifikan hasil belajar kognitif siswa antara kelas eksperimen dan kelas kontrol dipengukuran akhir.
\end{abstract}

Kata kunci: contextual teaching and learning (CTL), motivasi, hasil belajar kognitif

\section{ABSTRACT}

This study aimed to describe the application of learning models Contextual Teaching And Learning (CTL) on motivation and cognitive learning outcomes in the material identifying how living things adapt to their environment VB State Elementary School 03 Ranyai Hilir.Forms of this research was Quasi Experimental Design with design Nonequivalent Control Group Design.Hypothesis test results post-questionnaire on the experimental class and control class obtained tcount (8.75)> t table (2.032), meaning that there are significant differences between students motivation experimental class and control class in the postquestionnaire.Hypothesis test results post-test on the experimental class and control class obtained tcount (6.219)> $t$ table (2.032), meaning that there is a significant difference between the students cognitive achievement experimental class and control class final measurement.

Keywords: contextual teaching and learning (CTL), motivation, cognitive learning outcomes 


\section{PENDAHULUAN}

Pendidikan merupakan sesuatu yang universal dan berlangsung terus menerus tak terputus dari generasi ke generasi dimanapun di dunia ini, guna untuk membentuk manusia yang cerdas baik itu cerdas intelegensinya, moralnya serta spiritualnya, Tirtarahardja (2008). Menurut UU No 2 Tahun 1989, Pasal 1, ayat (1), "pendidikan adalah usaha sadar untuk menyiapkan siswa melalui kegiatan bimbingan, pengajaran dan atau latihan bagi peranannya dimasa yang akan datang". Pendidikan sebagai usaha sadar yang sistematis selalu bertolak dari sejumlah landasan serta mengindahkan sejumlah asas-asas tertentu. Asas tersebut salah satunya adalah asas Tut Wuri Handayani yang intinya menegaskan bahwa setiap orang mempunyai hak mengatur dirinya sendiri dengan mengingat tertibnya persatuan dalam perikehidupan umum serta mengganti sistem pendidikan cara lama yang menggunakan perintah, paksaan dan hukuman dengan sistem khas Taman Siswa, dimana guru hanya bertindak sebagai fasilitator dan motivator bagi siswa untuk menggali pengetahuannya sendiri, Mudyahardjo (2008). Jadi pendidikan pada dasarnya merupakan usaha yang dilakukan untuk menyiapkan siswa di masa yang akan datang dan dilaksanakan secara terus menerus.

Pendidikan tidak lepas dari dua kegiatan, yaitu kegiatan belajar dan mengajar. Ini berarti berhasil tidaknya pencapaian tujuan pendidikan banyak tergantung pada bagaimana proses belajar yang dialami siswa baik di sekolah, di rumah maupun di lingkungan masyarakat. Walaupun pencapaian tujuan pendidikan sangat bergantung pada diri siswa, namun peran guru sebagai pendidik juga tidak kalah pentingnya di dalam memotivasi, mendukung dan memfasilitasi tercapainya tujuan pembelajaran pada diri siswa tersebut.Oleh karena itu, guru dituntut untuk memiliki kemampuan yang profesional di dalam pembelajaran.

Guru yang dikatakan profesional, tidak hanya memiliki kemampuan di dalam menyampaikan materi saja, tetapi juga menyangkut kemampuan di dalam memilih maupun mengunakan model, pendekatan, strategi, metode, media serta pembelajaran yang bervariasi. Dengan pembelajaran yang bervariasi, maka siswa akan lebih termotivasi dan berminat di dalam mengikuti proses pembelajaran yang dilaksanakan, dan yang pastinya motivasi dan minat belajar tersebut akan berdampak pada hasil belajar yang diperoleh siswa. Namun kenyataannya, salah satu masalah yang dihadapi dunia pendidikan kita adalah masalah lemahnya proses pembelajaran, sehingga motivasi siswa dalam mengikuti proses pembelajaran juga rendah. Hal ini dapat mempengaruhi hasil belajar yang didapat oleh siswa tersebut.

Ada beberapa faktor yang dapat mempengaruhi hasil belajar siswa, yaitu yang pertama faktor eksternal atau faktor dari luar individu misalnya: keadaan udara, suhu udara, cuaca, waktu, tempat belajar, dan lain-lain. Serta faktor yang kedua adalah faktor internal atau faktor dari dalam diri individu yang terbagi menjadi dua, yaitu faktor fisiologis yang meliputi keadaan jasmani dan keadaan fungsi-fungsi fisiologis, serta faktor psikologis yang meliputi minat, kecerdasan, Setyaningsih (2013).

Proses pembelajaran di dalam kelas diarahkan kepada kemampuan siswa untuk menghafal informasi atau lebih kepada ranah kognitif. Otak siswa dipaksa mengingat dan menimbun berbagai informasi tanpa dituntut untuk memahami dan menggali sendiri pengetahuannya itu serta menghubungkan informasi yang diperoleh tersebut dengan kehidupan sehari-hari.Sehingga, siswa cerdas secara teoritis, tetapi mereka miskin aplikasinya. Kesulitan lain dan merupakan permasalahan terbesar yang dihadapi para siswa sekarang adalah mereka belum bisa menghubungkan antara apa yang mereka pelajari dan bagaimana pengetahuan itu akan digunakan. Hal ini dikarenakan cara mereka memperolah informasi belum tersentuh oleh model pembelajaran yang betul-betul bisa membantu mereka. Para siswa kesulitan untuk memahami konsep-konsep akademis (seperti konsepkonsep matematika, IPA, dan lain-lainnya), karena model ataupun metode mengajar yang selama ini digunakan oleh guru hanya terbatas pada metode ceramah.

Padahal sebenarnya, untuk memperkuat dimilikinya pengalaman belajar yang aplikatif bagi siswa, tentu memerlukan pembelajaran yang lebih banyak memberikan kesempatan kepada siswa untuk melakukan, mencoba, dan mengalami sendiri (learning to do), dan bukan sekedar sebagai pendengar yang pasif yang hanya sebagai penerima terhadap 
semua informasi yang disampaikan guru. Proses pembelajaran dikatakan berhasil bila mencapai tujuan yang optimal serta dapat membuat siswa mengalami proses belajar. Sedangkan, pembelajaran yang pada hakikatnya belum dapat membuat siswa mengalami proses belajar belum bisa disebut pembelajaran, tetapi mungkin baru sekedar menyampaikan materi pelajaran. Suatu proses pembelajaran yang baik haruslah bersifat interaktif, sehingga dapat memberikan ruang kepada siswa untuk dapat berpartisipasi aktif dalam proses pembelajaran, serta menerapkan proses pembelajaran yang holistik, yang bertujuan memotivasi siswa untuk memahami makna materi pelajaran yang dipelajarinya dengan mengaitkan materi tersebut dengan konteks kehidupan mereka sehari-hari (konteks pribadi, sosial, dan kultural) sehingga siswa memiliki pengetahuan atau keterampilan yang secara fleksibel dapat diterapkan atau ditransfer dari satu permasalahan atau konteks ke permasalahan atau konteks lainnya.

Dalam kegiatan observasi yang dilakukan oleh peneliti di Sekolah Dasar Negeri 03 Ranyai Hilir pada hari Senin tanggal 20 Juli 2016 di Kelas VB, Peneliti menemukan bahwa secara umum motivasi belajar siswa masih kurang. Hal ini ditunjukan bahwa masih banyak siswa yang sibuk sendiri ketika guru menjelaskan materi pelajaran, tidak mengerjakan tugas ketika tugas diberikan.Selain itu, hasil belajar siswa/i juga masih banyak yang di bawah kriteria ketuntasan minimum (KKM) yaitu 60 (enam puluh). Hal ini dibuktikan dari hasil ulangan harian sebelumnya pada mata pelajaran IPA, di mana dari 18 siswa hanya 6 siswa atau $33,33 \%$ yang mencapai kriteria ketuntasan minimum (KKM). Sedangkan 12 orang siswa atau $66,66 \%$ siswa lainnya belum mencapai nilai ketuntasan minimum (KKM). Maka peneliti beranggapan bahwa hal ini bisa saja terjadi karena beberapa faktor diantaranya guru belum mampu menciptakan suasana belajar yang kondusif.

Dalam hal ini guru berkewajiban menciptakan kegiatan belajar mengajaryang mampu menunjang dan mendorong siswa untuk mengembangkan segalapotensi yang ada secara optimal, sehingga keberhasilan itu dapat diperoleh siswa.Selain itu, pembelajaran di sekolah seharusnya tidak hanya difokuskan pada pemberian pembekalan kemampuan pengetahuan yang bersifat teoritis saja atau dengan kata lain pengetahuan sebagai fakta untuk dihafal, akan tetapi bagaimana agar pengalaman belajar yang dimiliki oleh siswa senantiasa terkait dengan permasalahan-permasalahan aktual yang terjadi di lingkungannya. Dengan demikian, pembelajaran selain akan lebih menarik juga akan dirasakan sangat dibutuhkan oleh setiap siswa, karena apa yang dipelajari dirasakan langsung manfaatnya, Rusman (2013).

Dengan model pembelajaran Contextual Teaching and Learning (CTL) yang memberikan fasilitas kegiatan belajar siswa untuk mencari, mengolah dan menemukan pengalaman belajar yang lebih bersifat konkrit, yaitu melalui keterlibatan siswa dalam mencoba, melakukan dan mengalami sendiri. Siswa akan lebih tertarik dan termotivasi untuk mengikuti proses pembelajaran, karena siswa merasa bahwa pembelajaran tersebut bermanfaat di dalam kehidupan mereka. Senada dengan itu, Johnson (2014) menegaskan bahwa "Contextual Teaching and Learning (CTL) menawarkan jalan menuju keunggulan akademis yang dapat diikuti oleh semua siswa. Hal itu bisa terjadi karena Contextual Teaching and Learning (CTL) sesuai dengan cara kerja otak dan prinsip-prinsip yang menyokong sistim kehidupan".

Sejalan dengan itu, Oktaviansa, W. A, dan Yunus (2013) dalam penelitian yang berjudul Pengaruh Model Pembelajaran Contextual Teaching and Learning (CTL) terhadap Motivasi dan Hasil Belajar Siswa SMK Negeri 1 Sidoarjo, menunjukkan bahwa dari nilai pre-test kelas kontrol memiliki rata-rata nilai kelas sebesar 73,7, sedangkan kelas eksperimen memiliki rata-rata nilai kelas sebesar 72,2 . Namun perbedaan yang signifikan tergambar pada hasil nilai, setelah perlakuan. Pada skala nilai $(0-100)$, nilai rata-rata kelas kontrol setelah perlakuan adalah 77,08, sedangakan nilai rata-rata untuk kelas eksperimen adalah 81,5.

Berdasarkan hal tersebut di atas, peneliti ingin mengetahui penerapan model pembelajaran Contextual Teaching and Learning (CTL) terhadap motivasi dan hasil belajar kognitif siswa, sehingga peneliti tertarik untuk melakukan penelitian yang berjudul penerapan model pembelajaran Contextual Teaching and Learning (CTL) terhadap motivasi dan hasil belajar kognitif pada materi Mengidentifikasi Cara Makhluk Hidup Menyesuaikan Diri dengan 
Lingkungannya siswa kelas V B Sekolah Dasar Negeri 03 Ranyai Hilir tahun pelajaran 2016/2017.

Rumusan masalah dalam penelitian adalah (a) bagaimana aktivitas mengajar guru kelas eksperimen menggunakan model pembelajaran Contextual Teaching and Learning (CTL) dan kelas kontrol menggunakan metode konvensional ?; (b) bagaimana aktivitas belajar siswa kelas eksperimen menggunakan model pembelajaran Contextual Teaching and Learning (CTL) dan kelas kontrol menggunakan metode konvensional ?; (c) apakah terdapat perbedaan yang signifikan motivasi belajar siswa antara kelas eksperimen dan kelas kontrol pada pre-angket ?; (d) apakah terdapat perbedaan yang signifikan motivasi belajar siswa antara kelas eksperimen dan kelas kontrol pada post-angket ?; (e) apakah terdapat perbedaan yang signifikan hasil belajar kognitif siswa antara kelas eksperimen dan kelas kontrol pada pre-test ?; (f) apakah terdapat perbedaan yang signifikan hasil belajar kognitif siswa antara kelas eksperimen dan kelas kontrol pada post-test ?; (g) bagaimana respon siswa terhadap penerapan model pembelajaran Contextual Teaching and Learning (CTL) pada materi Mengidentifikasi Cara Makhluk Hidup Menyesuaikan Diri dengan Lingkungannya di kelas V Sekolah Dasar Negeri 03 Ranyai Hilir tahun pelajaran 2016/2017 ?

Tujuan dalam penelitian adalah (a) mendeskripsikan aktivitas mengajar guru kelas eksperimen menggunakan model pembelajaran Contextual Teaching and Learning (CTL) dan kelas kontrol menggunakan metode konvensional; (b) mendeskripsikan aktivitas belajar siswa kelas eksperimen menggunakan model pembelajaran Contextual Teaching and Learning (CTL) dan kelas kontrol menggunakan metode konvensional; (c) mendeskripsikan perbedaan yang signifikan motivasi belajar siswa antara kelas eksperimen dan kelas kontrol pada pre-angket; (d) mendeskripsikan perbedaan yang signifikan motivasi belajar siswa antara kelas eksperimen dan kelas kontrol pada post-angket; (e) mendeskripsikan perbedaan yang signifikan hasil belajar kognitif siswa antara kelas eksperimen dan kelas kontrol pada pre-test; (f) mendeskripsikan perbedaan yang signifikan hasil belajar kognitif siswa antara kelas eksperimen dan kelas kontrol pada post-test; (g) mendeskripsikan respon siswa terhadap penerapan model pembelajaran Contextual Teaching and Learning (CTL) pada materi Mengidentifikasi Cara Makhluk Hidup Menyesuaikan Diri dengan Lingkungannya di kelas V Sekolah Dasar Negeri 03 Ranyai Hilir tahun pelajaran 2016/2017.

\section{METODE PENELITIAN}

Metode penelitian yang digunakan yaitumetode penelitian eksperimen, bentuk penelitiannya Quasi Eksperimental Design.Bentuk penelitian ini mempunyai kelompok kontrol, tetapi tidak dapat berfungsi sepenuhnya untuk mengontrol variabel-variabel luar yang mempengaruhi pelaksanaan eksperimen, Sugiyono (2013).Desain penelitian yang digunakan adalah Nonequivalent Control Group Design. Desain ini hampir sama dengan Pretest-Posttest Control Group Design, hanya pada desain ini kelompok eksperimen maupun kelompok kontrol tidak dipilih secara random.Populasi dalam penelitian ini adalah siswa/i kelas V SD Negeri 03 Ranyai Hilir yang berjumlah 36 orang yang terbagi dalam 2 kelas, yaitu:

Tabel 1. Populasi Penelitian

\begin{tabular}{ccc}
\hline No. & Kelas & Jumlah \\
\hline 1. & VA & 18 \\
2. & VB & 18 \\
& Jumlah & 36 \\
\hline \multirow{2}{*}{ Sumber: SD Negeri 03 } & Ranyai Hilir(2016)
\end{tabular}

Sampel dalam penelitian ini terbagi menjadi dua kelas, yaitu kelas eksperimen dan kelas kontrol.Kelas VA yang berjumlah 18 siswa sebagai kelas kontrol dan kelas VB yang berjumlah 18 siswa sebagai kelas eksperimen. 
Tabel 2. Sampel Penelitian

\begin{tabular}{cccl}
\hline No. & Kelas & Jumlah & Keterangan \\
\hline 1. & VA & \multirow{2}{*}{18} & Kelas Kontrol \\
2. & VB & 18 & Kelas \\
& & & Eksperimen \\
\hline
\end{tabular}

Sumber: SD Negeri 03 Ranyai Hilir (2016)

Teknik dalam pengambilan sampel dilakukan dengan cara sampling jenuh. Sampling jenuh yaitu teknik penentuan sampel bila semua anggota populasi digunakan sebagai sampel.

Instrumen pengumpulan data dalam penelitian dibagi menjadi dua, yaitu: instrumen pengumpulan data untuk variabel bebas dan instrumen pengumpulan data untuk variabel terikat. Instrumen pengumpulan data variabel bebas meliputi silabus, rencana pelaksanaan pembelajaran (RPP), lembar kerja siswa (LKS), lembar observasi, lembar angket respon siswa, dan dokumentasi.Instrumen pengumpulan data variabel terikat meliputi lembar angket motivasi belajar siswa, dan soal tes.

Teknik analisis data yang digunakan adalah analisis observasi manggunakan rumus persentase, analisis motivasi belajar siswa menggunakan rumus persentase, analisis hasil belajar kognitif siswa menggunakan rumus ketuntasan belajar, uji normalitas dan homogenitas data menggunakan aplikasi SPSS 16.0, uji hipotesis menggunakan rumus uji statistik parametrik yaitu uji t-test sampel related, analisis respon siswa menggunakan rumus persentase.

\section{HASIL DAN PEMBAHASAN PENELITIAN}

Berdasarkan analisis perhitungan aktivitas mengajar guru menggunakan rumus persentase pada kelas eksperimen dan kelas kontrol pada pertemuan pertama dan pertemuan kedua sebagai berikut:

Tabel 3. Aktivitas Mengajar Guru

\begin{tabular}{ccc}
\hline No. & Kelas & Rata-rata $(\%)$ \\
\hline 1. & Eksperimen & 95,83 \\
2. & Kontrol & 96,42 \\
\hline
\end{tabular}

Hasil rata-rata pertemuan pertama dan kedua aktivitas mengajar guru kelas eskperimen sebesar $95,83 \%$ berkriteria sangat baik (SB). Rata-rata pertemuan pertama dan kedua aktivitas mengajar guru kelas kontrol sebesar 96,42\% berkriteria sangat baik (SB).

Hasil analisis perhitungan aktivitas belajar siswa menggunakan rumus persentase pada kelas eksperimen dan kelas kontrol pada pertemuan pertama dan pertemuan kedua sebagai berikut:

Tabel 4. Aktivitas Belajar Siswa

\begin{tabular}{ccc}
\hline No. & Kelas & Rata-rata $(\%)$ \\
\hline 1. & Eksperimen & 92,93 \\
2. & Kontrol & 90,66 \\
\hline
\end{tabular}

Hasil rata-rata pertemuan pertama dan kedua aktivitas belajar siswa kelas eskperimen sebesar $92,93 \%$ berkriteria sangat baik (SB). Rata-rata pertemuan pertama dan kedua aktivitas belajar siswa kelas kontrol sebesar $90,66 \%$ berkriteria sangat baik (SB).

Hasil tersebut sesuai dengan pendapat Rusman (2013), yang menyatakan bahwa pembelajaran kontekstual adalah usaha untuk membuat siswa aktif dalam memompa kemampuan diri tanpa merugi dari segi manfaat, sebab siswa berusaha mempelajari konsep sekaligus menerapkan dan mengaitkannya dengan dunia nyata.

Hasil analisis motivasi belajar siswa di kelas eksperimen pada pengukuran awal (preangket) dan pengukuran akhir (post-angket)disajikan pada tabel 5 sebagai berikut: 
Tabel 5. Nilai Hasil Pre-angket danPost-angket Kelas Eksperimen

\begin{tabular}{lccc}
\hline Pelaksanaan & \multicolumn{2}{c}{ Nilai } & \multirow{2}{*}{ Mean } \\
\cline { 2 - 3 } \multicolumn{1}{c}{ Tesendah } & Tertinggi & \\
\hline Pre-angket & 40 & 60 & 32,22 \\
Post-angket & 72 & 98 & 85,22
\end{tabular}

Hasil analisis motivasi belajar siswa di kelas kontrol pada pengukuran awal (pre-angket) dan pengukuran akhir (post-angket) disajikan pada tabel sebagai berikut:

Tabel 6. Nilai Hasil Pre-angket danPost angket Kelas Kontrol

\begin{tabular}{cccc}
\hline Pelaksanaan & \multicolumn{2}{c}{ Nilai } & Mean \\
\cline { 2 - 4 } Tes & Terendah & Tertinggi & \\
\hline Pre-angket & 20 & 60 & 31,66 \\
Post-angket & 40 & 90 & 57,22
\end{tabular}

Hasil perhitungan indeks gain hake, motivasi belajar siswa baik di kelas eksperimen maupun di kelas kontrol, selengkapnya dapat dilihat pada tabel 7 di bawah ini:

Tabel 7. Hasil Perhitungan Indeks Gain Hake MotivasiBelajar Siswa di Kelas Eksperimen dan Kelas Kontrol

\begin{tabular}{ccc}
\hline Kelas & Indeks Gain Hake & Kategori \\
\hline Eksperimen & 0,80 & Baik Sekali \\
Kontrol & 0,43 & Cukup \\
\hline
\end{tabular}

Hasil penelitian ini sejalan dengan penelitian yang dilakukan oleh peneliti sebelumnya, Oktaviansa, W. A, dan Yunus (2013),dengan judul Pengaruh Model Pembelajaran Contextual Teaching and Learning (CTL) terhadap Motivasi dan Hasil Belajar Siswa SMKN 1 Sidoarjo, yang memperoleh hasil motivasi belajar di kelas kontrol lebih kecil dibandingkan dengan motivasi belajar yang didapat di kelas eksperimen. Hal ini karena siswa di kelas eksperimen lebihaktif dan ekspresif di bandingkan dengan kelas yang menggunakan model pembelajaran konvensional.

Hasil belajar kognitif siswa pada penelitian ini dilihat dari pre-test dan post-test siswa. Hasil belajar kognitif siswa kelas eksperimen dalam penelitian ini dapat dilihat pada tabel 8 sebagai berikut:

Tabel 8. Nilai Hasil Pre-test dan Post-test Kelas Eksperimen

\begin{tabular}{cccc}
\hline Pelaksanaan Tes & \multicolumn{2}{c}{ Nilai } & Mean \\
\cline { 2 - 3 } & Terendah & Tertinggi & \\
\hline Pre-test & 30 & 65 & 51,11 \\
Post-test & 60 & 100 & 81,66 \\
\hline
\end{tabular}

Hasil belajar kognitif siswa kelas kontrol dalam penelitian ini dapat dilihat pada tabel 9 sebagai berikut:

Tabel 9. Nilai Hasil Pre-test dan Post-test Kelas Kontrol

\begin{tabular}{cccc}
\hline PelaksanaanTes & \multicolumn{2}{c}{ Nilai } & Mean \\
\cline { 2 - 3 } & Terendah & Tertinggi & \\
\hline Pre-test & 35 & 65 & 49,72 \\
Post-test & 55 & 95 & 65,27
\end{tabular}


Jimi, dkk | Pengaruh model pembelajaran contextual teaching...

Hasil perhitungan indeks gain hake, hasil belajar kognitif siswa baik di kelas eksperimen maupun di kelas kontrol, selengkapnya dapat dilihat pada tabel 10sebagai berikut:

Tabel 10. Hasil Perhitungan Indeks Gain Hake Hasil Belajar Kognitif Siswa di Kelas Eksperimen dan Kelas Kontrol

\begin{tabular}{ccc} 
Kelas & Indeks Gain Hake & Kategori \\
\hline Eksperimen & 0,62 & Baik \\
Kontrol & 0,34 & Cukup \\
\hline
\end{tabular}

Hasil penelitian ini sejalan dengan penelitian yang dilakukan oleh Oktaviansa, W.A, dan Yunus (2013),yang berjudul Pengaruh Model Pembelajaran Contextual Teaching and Learning (CTL) terhadap Motivasi dan Hasil Belajar Siswa SMKN 1 Sidoarjo.

Hasil penelitian tersebut menunjukkan bahwa, nilai pre-test di kelas kontrol memiliki rata-rata sebesar 73,7, sedangkan kelas eksperimen memiliki rata-rata nilai sebesar 72,2. Namun perbedaan yang signifikan tergambar pada hasil nilai, setelah diberi perlakuan, nilai rata-rata kelas kontrol adalah 77,08 , sedangkan nilai rata-rata untuk kelas eksperimen adalah 81,5.

Berdasarkan analisis uji prasyarat diketahui bahwa data yang digunakan berdistribusi normal dan homogen. Oleh karena itu uji hipotesis yang digunakan pada penelitian ini adalah uji statistik parametrik yakni dengan uji t-test sampel related. Perbedaan motivasi belajar siswa antara kelas eksperimen dan kelas kontrol pada pengukuran awal (pre-angket) dapat dilihat pada tabel 11 sebagai berikut:

Tabel 11. Uji Perbedaan Motivasi Belajar Siswa Kelas Eksperimen dan Kelas Kontrol pada Pre-angket

\begin{tabular}{cccc}
\hline Kelas & $t_{\text {hitung }}$ & $\begin{array}{c}\mathrm{Dk} \\
(36-2)\end{array}$ & $\mathrm{t}_{\text {tabel }}$ \\
\hline $\begin{array}{c}\text { Eksperimen } \\
\text { Kontrol }\end{array}$ & 0,20 & 34 & 2,032 \\
\hline
\end{tabular}

Berdasarkan tabel 11di atas terlihat bahwa hasil analisis tersebut menunjukan nilai $t_{\text {hitung }}$ lebih kecil daripada nilai $t_{\text {tabel }}(0,20<2,032)$ yang artinya tidak terdapat perbedaan yang signifikanmotivasi belajar siswa kelas eksperimen dan kelas kontrol pada pengukuran awal (pre-angket).

Selanjutnya, analisis uji hipotesis motivasi belajar siswa pada pengukuran akhir postangketkelas eksperimen dan kelas kontrol dapat dilihat pada tabel 12 sebagai berikut:

Tabel 12. Uji Perbedaan Motivasi Belajar Siswa Kelas Eksperimen dan Kelas Kontrol pada Post-angket

\begin{tabular}{lccc}
\hline \multicolumn{1}{c}{ Kelas } & thitung & $\begin{array}{c}\text { Dk } \\
(36-2)\end{array}$ & t $_{\text {tabel }}$ \\
\hline $\begin{array}{l}\text { Eksperimen } \\
\text { Kontrol }\end{array}$ & 8,72 & 34 & 2,032 \\
\hline
\end{tabular}

Berdasarkan tabel 12 terlihat bahwa hasil analisis tersebut menunjukan bahwa nilai $t_{\text {hitung }}$ lebih besar daripada nilai $t_{\text {tabel }}(8,72>2,032)$ yang artinya terdapat perbedaan yang signifikan motivasi belajar siswa kelas eksperimen dan kelas kontrol pada pengukuran akhir (postangket).

Perbedaan hasil belajar kognitif siswa antara kelas eksperimen dan kelas kontrol pada pengukuran awal (pre-test) dapat dilihat pada table 13 sebagai berikut: 
Tabel 13. Uji Perbedaan Hasil Belajar Kognitif Siswa Kelas Eksperimen dan Kelas Kontrol pada Pre-test

\begin{tabular}{lccc}
\hline Kelas & $t_{\text {hitung }}$ & $\begin{array}{c}\text { Dk } \\
(36-2)\end{array}$ & $t_{\text {tabel }}$ \\
\hline $\begin{array}{l}\text { Eksperimen } \\
\text { Kontrol }\end{array}$ & 0,599 & 34 & 2,032 \\
\hline
\end{tabular}

Berdasarkan Tabel 13 di atas, terlihat bahwa hasil analisis tersebut menunjukan nilai $t_{\text {hitung }}$ lebih kecil daripada nilai $t_{\text {tabel }}(0,599<2,032)$ yang artinya tidak terdapat perbedaan yang signifikanhasil belajar kognitif siswa kelas eksperimen dan kelas kontrol pada pengukuran awal (pre-test).

Selanjutnya, analisis uji hipotesis hasil belajarkognitif siswa pada pengukuran akhir posttestkelas eksperimen dan kelas kontrol dapat dilihat pada tabel 14 sebagai berikut:

Tabel 14. Uji Perbedaan Hasil Belajar Kognitif Siswa Kelas Eksperimen Dan Kelas Kontrol pada Post-test

\begin{tabular}{cccc}
\hline Kelas & $t_{\text {hitung }}$ & $\begin{array}{c}\text { Dk } \\
(36- \\
2)\end{array}$ & $t_{\text {tabel }}$ \\
\hline $\begin{array}{l}\text { Eksperimen } \\
\text { Kontrol }\end{array}$ & 6,219 & 34 & 2,032 \\
\hline
\end{tabular}

Berdasarkan tabel 14 di atas, terlihat bahwa hasil analisis tersebut menunjukan bahwa nilai $t_{\text {hitung }}$ lebih besar daripada nilai $t_{\text {tabel }}(6,219>2,032)$ yang artinya terdapat perbedaan yang signifikanhasil belajar kognitif siswa kelas eksperimen dan kelas kontrol pada pengukuran akhir (post-test).

Kemudian dilakukan analisis angket respon siswa setelah post-test. Pemberian angket respon siswa ini bertujuan untuk mengetahui tanggapanatau respon siswa setelah belajar menggunakan model Pembelajaran Contextual Teaching And Learning (CTL) dapat dilihat pada tabel 15 sebagai berikut:

Tabel 15. Hasil Angket Respon Siswa terhadap Model Pembelajaran Contextual Teaching And Learning (CTL)

\begin{tabular}{ccccc}
\hline Pernyataan & \multicolumn{4}{c}{ Jawaban } \\
\cline { 2 - 5 } & SS & S & TS & STS \\
\hline Jumlah & 888,83 & 72,18 & 5,55 & 33,3 \\
Rata-rata & 88,88 & 7,21 & 0,55 & 3,33 \\
& Tanggapan positif $96 \%$ & \multicolumn{3}{c}{ Tanggapan negatif } \\
& \multicolumn{3}{c}{$4 \%$} \\
\hline
\end{tabular}

Berdasarkan gambar 15 di atas, dapat diketahui bahwa respon siswa terhadap penerapan model pembelajaran Contextual Teaching And Learning (CTL), pada kategori jawaban sangat setuju (SS), memperoleh rata-rata tertinggi, yaitu sebesar $88,88 \%$, rata-rata respon tertinggi kedua berada pada kategori jawaban setuju (S), yaitu sebesar $7,21 \%$, ratarata respon siswa pada kategori jawaban tidak setuju (TS), yaitu sebesar 0,55\%, dan ratarata respon siswa pada kategori jawaban sangat tidak setuju (STS), yaitu sebesar 3,33\%. Artinya respon siswa kelas eksperimen yang memberi tanggapan positif terhadap penerapan model pembelajaran Contextual Teaching And Learning (CTL), yaitu sebesar 96,09\%, dibulatkan menjadi $96 \%$ dan yang memberi tanggapan negatif sebesar $3,88 \%$, dibulatkan menjadi $4 \%$.

Hal ini sesuai dengan pendapat Shoimin (2014) yang mengatakan bahwa karakteristik dari pembelajaran Contextual Teaching And Learning (CTL), diantaranya, dapat membuat siswa belajar dengan bergairah, menyenangkan dan tidak membosankan. Pendapat ini semakin dipertegas dengan hasil penelitian Oktaviansa, W. A, dan Yunus (2013),dengan judul penelitian Pengaruh Model Pembelajaran Contextual Teaching and Learning (CTL) 
terhadap Motivasi dan Hasil Belajar Siswa SMKN 1 Sidoarjo, yang mengatakan bahwa dengan model pembelajaran Contextual Teaching and Learning (CTL), banyak diantara peserta didik yang lebih bersemangat dan antusias di dalam proses pembelajaran karena dapat merasakan susah senang, kepuasan dan kekompakan kerja sama dalam suatu team work.

\section{SIMPULAN}

Berdasarkan analisis data secara statistik yang diperoleh dari hasil angket motivasi belajar siswa dan hasil tes siswa dapat disimpulkan secara umum nilai post-test kelas eksperimen dan kelas kontrol setelah dibandingkan ternyata memiliki perbedaan yang berbeda nyata. Hal ini berarti terdapat perbedaan yang signifikan antara motivasi dan hasil belajar kognitif siswa di kelas eksperimen yang menggunakan model pembelajaran Contextual Teaching And Learning (CTL) dengan motivasi dan hasil belajar kognitif siswa di kelas kontrol yang menggunakan metode konvensional (ceramah) pada materi mengidentifikasi cara makhluk hidup menyesuaikan diri dengan lingkungannya di SD Negeri 03 Ranyai Hilir.Berdasarkan sub-sub masalah yang ada, maka dapat disimpulkan hal-hal sebagai berikut: (a) Hasil observasi aktivitas mengajar guru di kelas eksperimen menggunakan model pembelajaran Contextual Teaching And Learning (CTL) pada pertemuan pertama sebesar $91,66 \%$, berkriteria sangat baik (SB), pada pertemuan kedua sebesar $100 \%$, berkriteria sangat baik (SB), dengan rata-rata pertemuan pertama dan pertemuan kedua sebesar 95,83\%, berada pada kriteria sangat baik (SB). Di kelas kontrol pada pertemuan pertama sebesar $92,85 \%$, pada pertemua kedua sebesar $100 \%$, berkriteria sangat baik (SB), dengan rata-rata pertemuan pertama dan pertemuan kedua sebesar $96,42 \%$, berada pada kriteria sangat baik (SB);(b) Hasil observasi aktivitas belajar siswa di kelas eksperimen pada pertemuan pertama sebesar 90,04\%, berkriteria sangat baik (SB), pada pertemuan kedua sebesar $95,83 \%$, dengan rata-rata pertemuan pertama dan pertemuan kedua sebesar 92,93\%, berkriteria sangat baik (SB). Di kelas kontrol pada pertemuan pertama sebesar $87,29 \%$, dengan kriteria baik (B), pada pertemua kedua sebesar $94,04 \%$, berkriteria sangat baik (SB), dengan rata-rata pertemuan pertama dan pertemuan kedua sebesar 90,66\%, berkriteria sangat baik (SB); (c) Tidak terdapat perbedaan yang signifikan motivasi belajar siswa antara kelas eksperimen dan kelas kontrol pada pengukuran awal (pre-angket), hal ini berdasarkan hasil uji t didapatkan $t_{\text {hitung }}(0,20)<$ $t_{\text {tabel }}(2,032)$, maka $\mathrm{H}_{\mathrm{a}}$ ditolak dan $\mathrm{H}_{\mathrm{o}}$ diterima; (d) Terdapat perbedaan yang signifikan motivasi belajar siswa antara kelas eksperimen dan kelas kontrol pada pengukuran akhir (post-angket), hal ini berdasarkan hasil uji t didapatkan $t_{\text {hitung }}(8,75)>t_{\text {tabel }}(2,032)$, maka $\mathrm{H}_{a}$ diterima dan $\mathrm{H}_{\mathrm{o}}$ ditolak; (e) Tidak terdapat perbedaan yang signifikan hasil belajar kognitif siswa antara kelas eksperimen dan kelas kontrol pada pengukuran awal (pre-test), hal ini berdasarkan hasil uji t didapatkan thitung $(0,599)<t_{\text {tabel }}(2,032)$, maka $\mathrm{H}_{a}$ ditolak dan $\mathrm{H}_{\circ}$ diterima; (f) Terdapat perbedaan yang signifikan hasil belajar kognitif siswa antara kelas eksperimen dan kelas kontrol pada pengukuran akhir (post-test), hal ini berdasarkan hasil uji $t$ didapatkan $t_{\text {hitung }}(6,219)>\mathrm{t}_{\text {tabel }}(2,032)$, maka $\mathrm{H}_{\mathrm{a}}$ diterima dan $\mathrm{H}_{\mathrm{o}}$ ditolak; $(\mathrm{g})$ Berdasarkan hasil analisis angket respon siswa terhadap model pembelajaran Contextual Teaching And Learning (CTL), siswa kelas eksperimen yang memberi tanggapan positif terhadap penerapan model pembelajaran Contextual Teaching And Learning (CTL), yaitu sebesar $96,09 \%$, dibulatkan menjadi $96 \%$ dan yang memberi tanggapan negatif sebesar $3,88 \%$, dibulatkan menjadi $4 \%$.

Berkaitan dengan keseluruhan hasil penelitian yang telah diuji, ada beberapa saran yang disampaikan oleh peneliti sebagai berikut: (a) Siswa diharapkan untuk selalu mempersiapkan diri sebelum memulai pembelajaran, berani bertanya dan mengemukakan pendapat pada materi yang belum dipahami serta tidak mudah menyerah dan terus belajar agar menjadi generasi muda yang berkualitas; (b) Guru diharapkan memiliki pengetahuan dan kemampuan yang cukup sehingga dapat memilih model pembelajaran yang kondusif, tepat dan mampu melibatkan siswa secara penuh dalam proses pembelajaran salah satunya adalah dengan mempertimbangkan penggunaan model pembelajaran Contextual Teaching And Learning (CTL) sebagai upaya alternatif peningkatan motivasi dan hasil belajar siswa; 
(c) Pihak sekolah diharapkan dapat meningkatkan mutu dan kualitas pembelajaran di kelas dengan menerapkan model-model pembelajaran yang lebih kreatif dan inofatif, sehingga siswa tertarik dan tidak bosan untuk mengikuti proses pembelajaran yang dilaksanakan; (d) Mengingat penelitian ini hanya terbatas pada materi mengidentifikasi cara makhluk hidup menyesuaikan diri dengan lingkungannya, maka perlu adanya penelitian yang lebih lanjut untuk mengetahui apakah model pembelajaran Contextual Teaching And Learning (CTL) dapat diterapakan dan memberikan hasil yang lebih baik lagi pada cakupan materi maupun mata pelajaran yang lainnya, khususnya ditingkat Sekolah Dasar.

\section{REFERENSI}

Johnson, E. B. (2014). CTL Contextual Teaching \& Learning Menjadikan Kegiatan BelajarMengajar Mengasyikkan dan Bermakna. Bandung. Kaifa.

Mudyahardjo, R. (2008). Filsafat Ilmu Pendidikan. Bandung. Remaja Rosdakarya.

Oktaviansa, A. W. dan Yunus. (2013). "Pengaruh Model Pembelajaran Contextual Teaching And Learning (CTL) terhadap Motivasi dan Hasil Belajar Siswa SMKN 1 Sidoarjo". JPTM, Volume 02. No. $01 \mathrm{Hal} 34-43$.

Rusman. (2013). Seri Manajemen Sekolah Bermutu Model-model Pembelajaran Mengembangkan Profesionalisme Guru. Jakarta. Rajagrafindo Persada.

Setyaningsih, R. (2013). "Penerapan Model Pembelajaran Group Investigation untuk Meningkatkan Motivasi dan Hasil Belajar Pesawat Sederhana pada Siswa Kelas V SDN 3 Selakambang Kabupaten Purbalingga".skripsi tidak diterbitkan. Semarang:: Fakultas IImu Pendidikan Universitas Negeri Semarang.

Shoimin, A. (2014).68 Model Pembelajaran Inovatif dalam Kurikulum 2013. Yogyakarta. ArRuzz Media.

Sugiyono. (2013). Metode Penelitian Pendidikan PendekatanKuantitatif, Kualitatif, dan R \& D. Bandung. Alfabeta.

Tirtarahardja, U. (2008). Pengantar Pendidikan. Jakarta. Rineka Cipta. 